\author{
Natalia Szczerbij \\ Przykarpacki Uniwersytet Narodowy \\ im. Wasyla Stefanyka, Iwano-Frankiwsk (Ukraina) \\ e-mail: natalia.shcherbii@pnu.edu.ua \\ ORCID: 0000-0002-1431-9595
}

\title{
HYBRYDALNE FORMY CZASOWNIKOWE W JĘZYKU POLSKIM I UKRAIŃSKIM
}

Jednym $z$ najbardziej rozpowszechnionych kierunków współczesnych badań językoznawczych jest analiza związków międzykategorialnych, szczególnie na materiale kilku języków.

Po raz pierwszy terminu hybrydalne formy czasownikowe użył rosyjski językoznawca Wiktor Winogradow w swojej pracy Русский язык. Грамиатическое учение о слове. Tym terminem badacz określa imiesłowy przymiotnikowe (гибридные глагольно-прилагательные фрормы). Hybrydalność tych form W. Winogradow wyjaśnia łączeniem cech przeciwstawnych części mowy - werbalnych oraz imiennych [Виноградов 1972, 208].

Według SJP [SJP, wersja elektroniczna] hybryda, hybrydowy, hybrydalny, hybrydyczny' to: 1. "coś, co składa się z różnych elementów, często do siebie niepasujacych".

Hybrydalne formy czasownikowe sa zjawiskiem o charakterze wieloaspektowym, znajdującym się na granicy kilku części mowy. Łączą cechy różnych części mowy oraz wykazują synkretyzm na poziomie morfologicznym i semantyczno-składniowym.

U podstaw „hybrydalności” leży teoria mieszanych części mowy Aleksandra Pieszkowskiego, która polega na wydzielaniu części mowy łączących w sobie kategorie charakterystyczne dla różnych klas, np.: czasu, przypadka, zwrotności, strony, liczby [Пешковский 2001, 104]. Do takich części mowy językoznawca zalicza rzeczowniki odczasownikowe, imiesłowy przymiotnikowe i przysłówkowe, które znajdują się na granicy imiennych i werbalnych części mowy [Пешковский 2001, 104].

W językoznawstwie polskim na określenie hybrydalnych form czasownikowych funkcjonuja terminy nieosobowe formy fleksyjne, formy fleksyjne niekongruentne (formy na -no, -to) lub formy nieokreślone (bezokolicznik oraz imiesłowy przysłówkowe i przymiotnikowe) [Grzegorczykowa, Laskowski 1999, 200-202], nieosobowe nieodmienne formy czasownika [Strutyński 2002, 178] oraz formy niefinitywne (bezokolicznik i imiesłów przysłówkowy), regularne derywaty odczasownikowe (imiesłowy przymiotnikowe oraz odsłownik) [Saloni 2012, 105]. Uwzględ- 
niając wyżej wymienione ujęcia, do zakresu terminu hybrydalne formy czasownikowe zaliczamy rzeczowniki odczasownikowe, imiesłowy przymiotnikowe, formy zakończone na -no, -to oraz bezokoliczniki. Charakterystyczne dla tych form jest współwystępowanie kategorii werbalnych oraz imiennych. W językach słowiańskich właściwości oraz liczba tych kategorii są zróżnicowane.

Wspólną cechą hybrydalnych form czasownikowych jest nie tylko wspólne pochodzenie (o którym będzie mowa przy poszczególnych analizach każdej $z$ wyżej wymienionych form), lecz także znaczenie procesualne oraz kategoria aspektu, która przede wszystkim przysługuje czasownikowi. W różnych językach słowiańskich stopień zbliżenia każdej hybrydalnej formy $z$ czasownikiem lub rzeczownikiem jest odmienny.

Z semantycznego punktu widzenia do form procesualnych zalicza się wyrazy, które wyrażają zmienność / niezmienność w czasie, tzn.: 1) finitywne formy czasownikowe (verbum finitum); 2) formy zakończone na -no, -to; 3) bezokoliczniki; 4) imiesłowy przysłówkowe; 5) rzeczowniki odczasownikowe zakończone na -nie, -cie o znaczeniu procesualnym.

Według kryterium słowotwórczego do formacji procesualnych zaliczane sa wyrazy pochodne od nazw pewnych procesów, tj.: 1) nazwy cech przedmiotów wynikające $z$ procesów - imiesłowy przymiotnikowe; 2) nazwy cech przedmiotów związane $z$ procesem - przymiotniki odczasownikowe (przymiotniki procesualne), np.: powtarzalny, szkodliwy, dbały, wędrowny // інтегрувальний, синтезувальний, розсувний, зливний; 3) nazwy cech procesów - imiesłowy przysłówkowe; 4) nazwy przedmiotów związane $z$ procesami - rzeczowniki odczasownikowe.

Czasownikowa kategoria aspektu jest transponowana od czasownika na inne pochodne części mowy - formy zakończone na -no, -to, imiesłowy przysłówkowe, imiesłowy przymiotnikowe oraz rzeczowniki odczasownikowe ze znaczeniem procesualnym. Zachowuja one prefiksy i sufiksy wyrazów podstawowych, np.: zrobiono, zrobiwszy, zrobiony, zrobienie // зроблено, зробивши, зроблений, brak formy rzeczownika odczasownikowego.

Wykładnikami aspektu sa odpowiednie afiksy. Morfem gramatyczny aspektu niedokonanego jest wyrażany przez sufiksy, a prefiksy sa nosicielami dokonaności zarówno w języku ukraińskim, jak i w polskim [Вихованець 2004, 253, 295]. Dokonaność / niedokonaność wyraża charakter trwania procesu: limitatywność / nielimitatywność, rezultatywność / nierezultatywność, semefaktywność / multiplikatywność itp. Różnorodne formacje czasownikowe łączą ogólnoczasownikowe kategorie, takie jak: przechodniość / nieprzechodniość, dokonaność / niedokonaność, personalność / impersonalność.

Celem niniejszego artykułu jest nie tylko próba porównania hybrydalnych form czasownikowych $w$ materiale pochodzacym $z$ języka polskiego i ukraińskiego, lecz także analiza tych form ze wspólnego punktu wi- 
dzenia - procesualności, a podmiotem analizy sa kategorie gramatyczne wyrażane przez hybrydalne formy czasownikowe w obu tych językach.

Zastosowanie metody porównawczej umożliwi wyodrębnienie tożsamych i odmiennych cech w obu językach oraz scharakteryzowanie stopnia zbliżenia tych form do czasownika lub rzeczownika, szczególnie dzięki kategorii zwrotności.

Przykłady zaczerpnięto $z$ tekstów literatury pięknej, uwzględnionych w korpusach języka ukraińskiego [KYM] i polskiego [NKJP], oraz - w odniesieniu do współczesnego języka potocznego $-z$ sieci Internet.

W dalszej części artykułu poddano szczegółowej analizie każdą z wyróżnionych form hybrydalnych.

Bezokolicznik jest specyficzna formacją międzykategorialną. Syntaktyczna osobliwość języka ukraińskiego polega na używaniu bezokolicznika w konstrukcjach, w których w języku polskim i rosyjskim przeważa rzeczownik odczasownikowy, np.: próba zrobienia czegoś спроба зробити иось.

Bezokolicznikom nie przysługują kategorie osoby, czasu i trybu, określające okoliczności, w których odbywa się czynność. Ich forma zawiera informację o przebiegu czynności (zakończona, jednorazowa, wielokrotna). Bezokolicznik jest nieodmienna formą czasownikowa, która oznacza proces, nie wskazując na wykonawcę i czas [Strutyński 2002, 178].

Cechy leksykalno-składniowe bezokolicznika zbliżają go do osobowej formy czasownikowej. Rozróżniamy bezokoliczniki dokonane i niedokonane, co świadczy o zachowaniu werbalnej kategorii aspektu: robić i zrobić, malować i namalować, myć i umyć, oraz jednokrotne i wielokrotne: mówić i mawiać, być i bywać, jeść i jadać.

Bezokoliczniki wyrażaja stronę czynna i zwrotną: myć i myć się, bić i bić się, czesać i czesać się. Niektóre czasowniki mają tylko stronę zwrotna tzw. reflexiva tantum: śmiać się, bać sie, kłaniać sie, chociaż jest to tylko formalna zbieżność $z$ formami zwrotnymi, ponieważ funkcji zwrotności te czasowniki nie wyrażają.

Bezokolicznik nie zawiera wykładników osobowo-czasowych i osobowo-trybowych, które sa obowiązujace dla osobowych form czasownika, dlatego tylko w połaczeniu $z$ formami analitycznymi może wyrażać relacje czasowe: będę pisać // бydy nucamu.

Bezokolicznik jako nazwa czynności jest podobny pod względem znaczenia i funkcji w zdaniu do rzeczownika odczasownikowego, np. bezokoliczniki chodzić i mówić nazywają te same czynności, co rzeczowniki odczasownikowe pisanie, chodzenie. $Z$ tego powodu w zdaniu bezokolicznik może pełnić taka samą funkcję jak rzeczownik - bezokolicznik występuje wprawdzie w pozycji syntaktycznie zależnej, może jednak być także użyty w funkcji członu syntaktycznie niezależnego (a więc konstytutywnego) wyrażenia zdaniowego [Grzegorczykowa 1999, 202]. W polskich konstrukcjach składniowych przy czasownikach fazowych oraz modal- 
nych można używać bezokolicznika lub rzeczownika odczasownikowego, np.: kończę tłumaczyć opowiadanie lub kończe ttumaczenie opowiadania; wole chodzic piechota lub wole chodzenie piechota; pragniemy wyzwolić się $z$ tego lub pragniemy wyzwolenia się $z$ tego. W języku polskim $\mathrm{w}$ porównaniu $z$ językiem ukraińskim częściej używa się rzeczownika odczasownikowego. Porównajmy: próba zrobienia (czegoś) - cnроба зробитu (uоoсъ); zezwolenie na wykorzystanie (czegoś) - дозвіл використати uృось; przeszkadzanie w robieniu (czegoś) - перешкоджання робити uјось; propozycja wygłoszenia (czegoś) - пропозищія виголосити (щось) [Кравчук 2015, 76-77].

Imiesłów przymiotnikowy to skomplikowana hybrydalna forma na granicy dwóch części mowy - czasownika oraz przymiotnika. Imiesłowowi przymiotnikowemu, podobnie jak czasownikowi, przysługuje kategoria czasu, aspektu oraz strony. Odmienia się jak przymiotnik przez przypadki, liczby oraz rodzaje. W języku ukraińskim podobnie jak w polskim w zdaniu pełni funkcję członu zależnego grupy imiennej (przydawki) [Жовтобрюх, Кулик 1972, 264]. Według binarnej fleksyjno-składniowej klasyfikacji części mowy Zygmunta Saloniego [Saloni 2012, 106-108] w języku polskim ze względu na swa prymarną funkcję składniowa przydawki oraz typ odmiany owe formy sa przymiotnikami relacyjnymi (przymiotniki odczasownikowe), a ich stosunek do czasowników jest taki sam jak np. przymiotników bywały, osiwiały, lecz omawiane leksemy Janusz Strutyński pozostawia w obrębie czasownika ze względu na zakorzeniona tradycję i praktykę szkolna [Strutyński 2002, 156]. W języku ukraińskim Iwan Wychowanec podobnie opisuje imiesłów przymiotnikowy jako синтаксичний $i$ морфологічний ад'єктив [Вихованець 1988, 176-179]. Henryk Wróbel w swoich starszych pracach przyjmował ugruntowany w gramatyce polskiej pogląd, że imiesłowy sa formami fleksyjnymi czasowników (stosując ujęcie Stanisława Jodłowskiego), czyli strukturami morfologicznymi tworzonymi w sposób mniej lub bardziej regularny według zasad polskiej fleksji czasownikowej [Wróbel 1975, 9], jednak w nowszych pracach stosuje inne ujęcie [Wróbel 2001].

Witalij Rusaniwski imiesłów przymiotnikowy interpretuje jako nieosobowa formę czasownika [Русанівський 1968, 408]. Hałyna Hnatiuk, autorka pracy monograficznej o imiesłowie przymiotnikowym w języku ukraińskim, wyodrębnia go jako samodzielna międzykategorialną część mowy, łączaca cechy czasownika i przymiotnika [Гнатюк 1982].

Cechą imiesłowów przymiotnikowych jest niwelacja procesualności oraz jej transformacja na odczasownikowa cechę przedmiotu w wyniku wykonywanej przez niego czynności lub właściwy dla niego stan [Вихованець 1988, 131].

W języku ukraińskim imiesłowy przymiotnikowe są tworzone znacznie rzadziej niż w języku rosyjskim i polskim. W języku rosyjskim od tego samego czasownika przechodniego możemy utworzyć cztery formy imiesłowu przymiotnikowego, np.: читающuй, читавщий, 
читаемый, читанный. Wynika to $z$ tego, że język rosyjski ma ma rozwinięte system i klasyfikacje nie tylko kategorii strony (страдательный и действительный залог), ale i w obrębie opozycji czasowej (imiesłowy teraźniejsze i przeszłe). Analogię do czynnego imiesłowu przeszłego można znaleźć w polskich przymiotnikach na -ły (sa to dawne imiesłowy), które Jan Tokarski uznaje za imiesłowy od dokonanych czasowników procesualnych [Tokarski 1951], np.: pożótkły, wyrudziały, upadły, były. Takie formy występuja jednak stosunkowo rzadko, a ich tworzenie nie charakteryzuje się automatyzmem [Nagórko 2007, 141].

W języku ukraińskim zgodnie ze szkolną gramatyką wyróżnia się czynne imiesłowy przymiotnikowe czasu teraźniejszego oraz przeszłego. Podobna klasyfikacja była kiedyś w polskiej gramatyce szkolnej. Imiesłowy czynne czasu teraźniejszego tworzy się od podstawy czasu teraźniejszego czasowników przechodnich i nieprzechodnich za pomoca sufiksów -уи (ий), -юч (ий), -ач (ий), -яч (ий): пекучий, стихаючий, сидячий, лежкачий. Imiesłowy przymiotnikowe czynne czasu przeszłego tworzy się od podstawy bezokolicznika czasowników nieprzechodnich aspektu dokonanego za pomoca sufiksu -л (ий): побілілий, посивілий, замерзлий, змарнілий [Козачук 2007, 171], lecz według niektórych językoznawców owe formy stanowią międzykategorialny typ pomiędzy imiesłowami a przymiotnikami [Вихованець, Городенська 2004, 147].

W języku ukraińskim używanie imiesłowów przymiotnikowych czynnych czasu teraźniejszego jest w znacznej mierze ograniczone i częstsze w literaturze pięknej [Куримо 1925, 9], w języku potocznym te formy prawie nie występuja. Porównajmy: синіючi далi, жовтіючі поля. Високу постать головнокомандувача шјодня бачили то в порту, то ще частіше - на горі Мітрідат, коли він у бінокль розглядав синіючий вдалині за протокою кубансъкий берег [Олесь Гончар]; Напівпрозорі жовтіючі та червоніючі кетяги солодко дрімають серед лапатого листя [Михаймо Коцюбинський].

Imiesłowy przymiotnikowe czynne czasu przeszłego na -uий, -вшuй, -чий, -мий są rzadko tworzone w języku ukraińskim, można znaleźć pojedyncze przykłady: здолавший, перемігший, оживший, озвірівший, посивівший, перемігший, допомігший oraz nieliczne imiesłowy na -лий: ожилий, озвірілий, посивілий, utworzone od prefiksalnych czasowników nieprzechodnich. Zamiast tych form używa się zdań podrzędnie złożonych, co jest bardziej naturalne w języku ukraińskim, np.: moŭ, якuй здолав; той, шо переміг.

W związku z tym można przyjąć, że opozycja imiesłowów przymiotnikowych wyrażona przez kategorię strony w języku ukraińskim w dużej mierze zaginęła, a zatem i kategoria strony nie jest tu właściwa. W języku ukraińskim imiesłowy przymiotnikowe bierne moga występować w czasie teraźniejszym lub przeszłym. Imiesłowy przymiotnikowe czasu teraźniejszego tworzy się od podstawy czasownika czasu teraźniejszego za pomoca sufiksów -yва-, -юва-, czasu przeszłego - od podstawy czasownika 


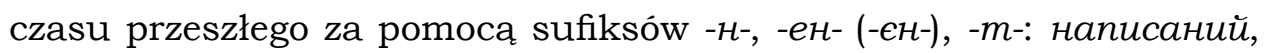
зроблений, помитий.

Gramatyki akademickie języka ukraińskiego odrzucają obecność kategorii czasu oraz strony w imiesłowach przymiotnikowych [Вихованець, Городенська 2004, 147-148]. Imiesłów przymiotnikowy nie wyraża stosunku do momentu mówienia, nie ma zatem trzech form czasownikowych. Niektóre imiesłowy przymiotnikowe oznaczają wykonywanie czynności w momencie mówienia (засихаюче дерево, сивіюча коса), a inne wskazuja na czynności, które poprzedzają wypowiedź (задуманий маневр, посинілий палеиъ). Wskazana przez imiesłów przymiotnikowy cecha nie jest związana $z$ czasem, ponieważ jego wykładniki kategorii czasu można neutralizować za pomoca transformacji. Wykładniki kategorii czasu to formy morfemu syntaktycznego бymu oraz cmamu, здаватися, робитися, лишитися, залишитися, зостатися itp. Na przykład: Цей транспортний засіб був зроблений з иілого стовбура дерева діаметром близько 1 м [Сергій Пустовалов]; Досі Антін здавався простим і зрозумілим. Все було в нім ясне, добре відоме, укладалося в рамки, а от... [Михайло Коцюбинський].

Język polski ma mniej form imiesłowów przymiotnikowych, lecz w porównaniu $z$ językiem ukraińskim ich tworzenie jest bardziej regularne, szczególnie w wypadku zapożyczeń i neologizmów, np.: program instalujacy; instagramujaca blogerka; Stałem sie nagle agresywny i drażliwy - mówi czatujacy od trzech lat 40-letni Marek. - Zaczałem wchodzić do pokoju czatowego ciagle pod nowym nickiem i obrzucać inwektywami tam obecnych [Krystyna Pytlakowska]. Polskie imiesłowy przymiotnikowe podobnie jak rosyjskie zachowuja aspektowe znaczenie czasownika oraz za pomoca specjalnych sufiksów (-ac-, -n-, -t-, -on-, -ęt-) wyrażaja gramatyczne znaczenie strony czynnej i biernej.

Imiesłowy te określaja cechy czynnościowe przedmiotów i osób, sa związane $z$ wykonywaniem czynności. Imiesłowy podkreślające czynność lub stan osób i przedmiotów nazywa się imiesłowami czynnymi. Imiesłowy czynne tworzy się od tematu czasu teraźniejszego za pomoca przyrostka -ac i końcówek rodzajowych: padajacy śnieg, śmiejąca się dziewczyna, płaczace dziecko.

Imiesłowy bierne określają osobę lub rzecz ze względu na bierne poddawanie się czynności. Tworzy się je od tematu czasu przeszłego i teraźniejszego czasowników czynnych przechodnich za pomoca przyrostków -ny, -ony, -ty, -ety: chwalony uczen, wyprana koszula, umyte dziecko, zmarznięte dzieci.

Imiesłowy czynne i bierne odmieniają się według wzorów deklinacji przymiotnikowej, a w liczbie mnogiej mają formy męskoosobowe i niemęskoosobowe: śpieszacy się ludzie, piszace kobiety, zaproszeni goście, wyróżnieni studenci. Wyżej wymienione przykłady na język ukraiński często tłumaczymy w sposób opisowy, ponieważ nie są one rozpowszechnione $\mathrm{i}$ tworzone tak regularnie jak w szyku polskim i rosyjskim, np. pi- 
szacy chłopiec - хлопеuь, який nuше; spieszacy się ludzie - люди, які cnimamb.

Oprócz tego język polski zachowuje zwrotny formant się, który może wskazywać na obecność strony zwrotnej z różnymi konotacjami (znaczenie rezultatywne, absolutywne, dekauzatywne itp.) [Щербій 2014a, 46], np.: Najemni wojownicy, bijacy się dla pieniędzy, okazuja się u mnie bardziej honorowi od walczacych za ojczyznę żotnierzy [Andrzej Sapkowski].

Imiesłowy przymiotnikowe zachowuja kategorię aspektu należna czasownikom oraz utrzymuja cechy rekcyjne form osobowych czasownika, tzn. zachowanie rządu przypadków zależnych przy imiesłowach czynnych, np. piszacy książkę, mówiacy o koledze, lub też - w wypadku imiesłowu biernego - właściwości rekcyjne imiesłowu sa regularnie (transformacyjnie) wyprowadzalne $z$ właściwości rekcyjnych form osobowych czasownika [Grzegorczykowa, Laskowski 1999, 82], np.: Kasia dała Andrzejowi książę - Ksią̇ka dana Andrzejowi przez Kasię. Ukraińskie konstrukcje bierne reprezentuja odmienna rekcję - subiekt w narzędniku w przeciwieństwie do polskiej konstrukcji z przyimkiem przez oraz biernikiem: Przecież nie miał jakiejkolwiek pewności, że przyjęty przez niego podział na strefy geograficzne jest prawidłowy... [Adam Barczyński]; Oднaк, ие не позбавляє ОМС права за власною ініиіативою або ініиіативою інших заінтересованих осіб змінити чи скасувати прийнятий ним правовий aкm [„Dziennik Ustaw Rady Najwyższej Ukrainy”].

Polskie imiesłowy przymiotnikowe nie wyrażaja gramatycznego znaczenia czasu. Obserwujemy tylko bierne formy czasu przeszłego, utworzone za pomoca przyrostków -an, -en, -on, -t: przeczytany, zrobiony, otwarty.

W konstrukcji biernej zmienna forma czasownika posiłkowego wyraża kategorię czasu, trybu, osoby oraz liczby, częściowo aspektu, w czasie przeszłym - rodzaj oraz formę męskoosobowa. Jako czasowniki posiłkowe występują czasowniki: być - szczególnie $z$ imiesłowami przymiotnikowymi w aspekcie niedokonanym, zostać-przede wszystkim $z$ imiesłowami $\mathrm{w}$ aspekcie dokonanym.

Formy zakończone na -no, -to. Wśród językoznawców brak jednomyślności co do terminologii form na -no, -to. Zwiazane jest to $z$ ich pochodzeniem.

W języku ukraińskim w zależności od typu cechy motywacyjnej wyróżnia się następujące terminy:

1) formy zakończone na -no, -to [Бумаховський 1948] - neutralne określenie, które świadczy tylko o formach jako zjawiskach gramatycznych;

2) czasownikowe formy zakończone na -no, -to, bezosobowe czasownikowe formy zakończone na -no, -to - określenia wskazujace na zwiazek $z$ czasownikiem;

3 imiesłowy przymiotnikowe zakończone na -no, -to, imiesłowowe formy zakończone na -no, -to, nieodmienne odimiesłowowe predykatywne 
formy na -no, -to [Гнатюк 1982] - określenia wskazujące na imiesłowowe pochodzenie tych form lub na inna cechę;

4) orzeczniki na -no, -to [Бумаховський 1948], orzecznikowa forma na -no, -to [Witalij Rusaniwski], odprzymiotnikowa orzecznikowa forma na -no, -to-określenia według składniowej funkcji;

5) bierne formy na -no, -to [Андерш 1987] - nazwa uwzględniająca kategorię strony;

6) bezosobowe zdania (konstrukcje) na -no, -to - nazwa ze względu na kategorię osobowości;

7) predykatywne formy na -no, -to, predykatywy na -no, -to, predykatywne orzecznikowe słowa na -no, -to [Русанівський 1968; СУМ] - nazwy wskazujace na predykatywny charakter tych form lub inna cechę;

8) perfekt na -no, -to [Wieczorek1994] - nazwa ze względu na kategorię czasu.

W języku polskim obserwujemy używanie terminów: predykatywna forma bezosobowa [Nagórko 2007], nieodmienne imiesłowy [Bak 1978], nieosobowe, nieodmienne formy czasownika [Strutyński 2002], nieosobowe formy fleksyjne, formy fleksyjne niekongruentne, formy na -no, -to, nieosobowe formy na -no, -to [Grzegorczykowa, Laskowski 1999].

$Z$ pochodzenia formy na -no, -to sa skostniałymi formami rzeczownikowej odmiany dawnych imiesłowów biernych rodzaju nijakiego zakończonych na -o. Imiesłowy te wchodziły w skład strony biernej: jest myto, było myto, jest robiono, było robiono. Gdy w tych formach zanikło słowo posiłkowe jest lub było, imiesłowy te otrzymały znaczenie czynne i do dziś pełnia funkcję orzeczenia nieosobowego w zdaniu. W językach rosyjskim i czeskim te formy zachowały swoja pierwotna postać, a w polskim i ukraińskim przekształciły się $\mathrm{w}$ formy czasownikowe na -no, -to, np. Centralka redakcji zarejestrowała godzine rozmowy i numer, $z$ którego dzwoniono [Tomasz Konatkowski].

Formy (zakończone) na -no, -to w przeciwieństwie do imiesłowów przymiotnikowych nie wskazuja na osobę, rodzaj czy liczbę, tzn. kategoria osoby jest zdeterminowana przez brak leksykalnej możliwości wypełnienia strukturalno-syntaktycznej pozycji podmiotu [Grzegorczykowa, Laskowski 1999, 200], np.: piszacy chłopiec (rodzaj męski, liczba pojedyncza) - piszaca dziewczyna (rodzaj żeński, liczba pojedyncza) - piszace dziecko (rodzaj nijaki, liczba pojedyncza) - piszace kobiety (rodzaj niemęskoosobowy, liczba mnoga) - piszacy studenci (rodzaj męskoosobowy, liczba mnoga) - dokumenty pisano (forma na -no, -to).

Podkreślanie czynności nie dotyczy ani nadawcy, ani odbiorcy, lecz samej formy -no, -to. Konstrukcje nieosobowe na -no, -to akcentuja czynność, a nie jej wykonawcę.

W języku polskim sa trzy typy konstrukcji do opisywania sytuacji bezosobowych, których wspólną cecha jest blokada syntaktycznej pozycji podmiotu. Osoba podmiotu, czyli wykonawca czynności lub nosiciel procesu czy stanu, jest w takich konstrukcjach nieokreślona, ponieważ 
mówiący nie chce jej wskazać lub nie jest w stanie jej nazwać [Grzegorczykowa, Laskowski 1999, 200]:

1) nieosobowe formy fleksyjne na -no, -to, np. mówiono, zrobiono, zbudowano;

2) konstrukcje $z$ morfemem się oparte na formie 3. os. lp. (rodzaju nijakiego). Takie formy językoznawcy nazywają słowiańskimi ergatywami. W konstrukcjach ergatywnych wykonawca czynności otrzymuje postać przypadka zależnego, więc na pierwsze miejsce wybija się sama czynność [Koneczna 1956, 385]: pracuje się, przeczytało się, będzie się chodziło // живеться, праиювалося, розвидниться. Afiks się $\mathrm{w}$ takich konstrukcjach nie odgrywa roli dopełnienia, lecz staje się formantem, który razem $z$ forma 3 . os. 1p. czasownika tworzy samodzielny typ słowotwórczo-semantyczno-składniowy [Щербій 2014b]. Ergatywy tworza czasowniki zarówno przechodnie, jak i nieprzechodnie obu aspektów, oznaczających czynności, stany konkretne i ogólne oraz procesy psychiczne i fizjologiczne. Możliwości języka ukraińskiego są w tym zakresie zasadniczo inne (por. też ukraińskie odpowiedniki funkcjonalne o innej formie, np. mówi się- говорять чи говоримо, tworzy sie - творять чи творимо itp.);

3) formy równokształtne $z$ 3. os. lp. rodzaju nijakiego - zasypało śniegiem, złamało mu noge.

Polskie i ukraińskie formy zakończone na -no, -to utworzone od czasowników przechodnich często w dopełnieniu maja biernik bez przyimka, dlatego takie konstrukcje sa czynne. W języku czeskim i rosyjskim podobne konstrukcje występują bardzo rzadko.

Ukraińskie formy na -no, -to w porównaniu $z$ polskimi straciły znaczenie przeszłości, lecz zachowały rezultatywność (jednokrotną w formach dokonanych i wielokrotna w formach niedokonanych). $Z$ tego powodu $\mathrm{w}$ języku ukraińskim używamy tych form $z$ czasownikiem posiłkowym було lub буде w celu podkreślenia zaprzeszłości lub przyszłości: ...докладний аналіз було зроблено у попередній лекиї ... [Andrij Domanowskyj]; Прем'єр заявив, шуо до кіния року бюджет буде повністю виконано, а також зазначив перевиконання річного плану [„Українська правда”] - w języku polskim nie rejestrujemy w NKJP używania form zakończonych na -no, -to $z$ czasownikami posiłkowymi. $\mathrm{W}$ takiej funkcji występuje imiesłów przymiotnikowy bierny: Może się doczekamy, że nasz plac będzie zrobiony tak jak Plac Wolności-powiedział jeden z mieszkańców [„Gazeta Poznańska”].

Język ukraiński nie tworzy form zakończonych na -Ho, -mo od czasowników zwrotnych na -cr, jak to mamy w języku polskim, gdzie formy na -no, -to sa motywowane bez ograniczeń przez wszystkie czasowniki, zachowujac zwrotny formant się: troszczono się, bawiono sie, odżywiano sie [Шербій 2016, 12]: W mroku pchano sie, walczono o to, kto pierwszy [Zofia Kossak]; Dyskutowano tam, witano się, weselono, kłócono [Andrzej Sapkowski]. 
Rzeczowniki odczasownikowe w ujęciach językoznawczych stanowią zagadnienie dyskusyjne. Zygmunt Saloni używa terminu odsłownik, który odnosi do rzeczowników na -nie/-cie typu pachnienie, wiedzenie, zaliczając takie formy do czasownikowych [Saloni 2004]. Stanisław Mędak używa podobnego terminu rzeczownik odsłowny, włacczając takie wyrazy do paradygmatu czasownikowego [Mędak 2004]. Witold Doroszewski zalicza takie formy do rzeczownika, ponieważ w Słowniku języka polskiego pod jego redakcja sa one określane jako forma rzeczownikowa czasownika [SJP wersja elektroniczna]. Stanisław Dubisz stosuje inne ujęcie, ponieważ większość rzeczowników odczasownikowych na -nie, -cie włącza do artykułów hasłowych o czasownikach w ramach paradygmatu czasownikowego: rozmyślanie książk. 'zastanawiać się nad czymś, rozważać, roztrząsać coś w myśli; medytować'. Jeżeli wyraz ma jeszcze inne dodatkowe znaczenie, autor wyróżnia to w oddzielnym artykule $z$ wyjaśnieniem: a) rzecz. od rozmyślać; b) medytacja, refleksja, także religijna [USJP, wersja elektroniczna].

Tworzenie oraz funkcjonowanie rzeczowników odczasownikowych w językach słowiańskich ma dawne prasłowiańskie pochodzenie, szczególnie wspólne sufiksy -nøje, -toje, które w każdym języku słowiańskim еwoluowały: ukr. лікування, пиття; pol. leczenie, picie; czes. zvyseni, zvysovdni; ros. исследование, развитие; biał. маучанне, жыииё; bułg. гледане; mac. oranje itp. [Пчелинцева 2019, 33].

Jadwiga Puzynina, autorka szczegółowej pracy o nazwach czynności w języku polskim, podobnie jak inni językoznawcy (Klára Buzássyová, Juraj Furdik, Hana Kř́žžková, Petr Karlík) wyodrębnia dwa typy rzeczowników odczasownikowych 1) kategorialne substantivum verbale (-anie, -enie, -cie, -eccie), które wg cech formalno-składniowych dażą do czasownika (tj. rzeczowniki czasownikowe); wśród nazw czynności takie derywaty odczasownikowe sa najliczniejsze, np.: mycie, bicie, chodzenie, robienie; 2) niekategorialne substantivum deverbale, tworzone za pomoca różnych formantów (około 80), zbliżające się przez to do rzeczownika, znaczeniowo nieregularne, np.: dyżur, handel, kontakt, zastrzyk, wykład, przedruk, wdech itp. [Puzynina 1969, 28-33].

$\mathrm{W}$ językoznawstwie wschodniosłowiańskim nie ma podziału na kategorialne i niekategorialne rzeczowniki odczasownikowe - wszystkie formacje sa rozumiane jako takie same konstrukcje słowotwórcze bez względu na ich zróżnicowana semantykę [Пчелинцева 2016].

W języku ukraińskim rzeczowniki odczasownikowe tworzy się za pomoca przyrostków słowotwórczych: -нн(я) (warianty -енн(я), -інн(я), -тm(я)): кохати - кохання, бути - буття, довіряти - довір'я; sufiks zerowy: nереходити - перехід; sufiks -א(a): орати - оранка. Ostatnie formy na $-\kappa(a)$ przecza dawnej ukraińskiej tradycji językowej, ponieważ sa one kalką $z$ języka rosyjskiego i określaja jedynie rezultat czynności, a nie same czynności czy zdarzenia. Jedną $z$ najważniejszych tendencji 
rozwojowych ukraińskiego języka specjalistycznego i terminologii w ogóle jest aktywizacja stricte ukraińskiego materiału leksykalnego i odrzucanie odpowiednich zapożyczeń. Dotyczy to przede wszystkim, jak twierdzą badacze, kalkowanych $z$ języka rosyjskiego rzeczowników odczasownikowych na $-k(a)$ zamiast $-H \mu(\Omega),-m m(\Omega)$, które sa dawną ukraińską tradycją językowa [Jóźwikiewicz 2008, 142].

Rzeczowniki odczasownikowe zakończone na -ння, -mmя// -anie, -enie, -cie, -eccie nazywają czynność trwająca, jeżeli są utworzone od czasowników niedokonanych, a te utworzone od czasowników dokonanych i niedokonanych nazywaja czynności będace rezultatami procesu [Куримо 2008, 77].

W językoznawstwie ukraińskim rzeczowniki odczasownikowe nie należą do paradygmatu czasownika, lecz są wyróżniane jako specyficzny typ rzeczownika. Czasownikowy charakter takich formacji potwierdzaja różne cechy: wspólne znaczenie procesualne, zachowanie przyrostków i przedrostków czasownika podstawowego, które sa wskaźnikami przynależności do pewnego aspektu, kategoria przechodniości, czasownikowa rekcja oraz walencja.

Rzeczowniki odczasownikowe zachowuja opozycję aspektową. W języku ukraińskim często brakuje jasnego rozumienia oraz zasad używania i tworzenia tych wyrazów, chociaż ta sytuacja powoli się zmienia: обстеження (zamiast обстежування) буде тривалим; наповнення (zamiast наповнювання) системи триватиме кілька годин [Городенська 2017, 19]. Dla języka ukraińskiego bardziej tradycyjne jest używanie konstrukcji czasownikowych $z$ bezokolicznikiem, imiesłowem przysłówkowym lub formami osobowymi czasownika. W języku polskim rzeczowniki odczasownikowe tworzy się od prawie wszystkich czasowników obu par aspektowych [Пчелинцева 2016, 160]: robienie-zrobienie, mycie - umycie, picie - wypicie, bicie - podbicie, pisanie - napisanie, malowanie - wymalowanie, otwieranie - otwarcie.

Kategoria aspektu zwiąana jest $z$ kategoria liczby, która determinuje czasownikowy lub rzeczownikowy charakter tych form, ponieważ rzeczowniki odczasownikowe używane są wyłącznie w liczbie pojedynczej, co wskazuje na abstrakcyjność, niepoliczalność czynności. W związku z tym używanie tych form w liczbie mnogiej przyczynia się do substantywizacji znaczenia leksykalnego, konkretyzacji i utraty semantyki aspektualnej, np.: Pośpiech przestuchań, a potem wykonania wyroków śmierci powinny budzić nieufność [Wojciech Żukrowski] - ważnym warunkiem używania rzeczowników odczasownikowych jest wyrażanie nieograniczonej ilości wykonywania danej czynności, oprócz tego wydzielone przykłady maja charakter substantywowany, sa terminami $z$ dziedziny prawa.

W języku polskim i ukraińskim obserwujemy produktywność tworzenia i używania nowych słów, derywowanych szczególnie od wyrazów zapożyczonych: esemesowanie, googlowanie, facebookowanie, instalo- 
wanie, blogowanie, instagramowanie, polubienie. W języku potocznym oraz na stronach internetowych spotykamy używanie nawet kilku takich leksemów w jednym zdaniu: Spodobało nam się blogowanie, facebookowanie, czas na instagramowanie [Internet].

Język ukraiński, w przeciwieństwie do rosyjskiego i polskiego, może za pomoca tylko czasownika czy rzeczownika odczasownikowego oraz kategorii aspektu wyraźnie dokonać rozróżnienia pomiędzy czynnością a zdarzeniem, np.: czynność - досліджування (aspekt niedokonany), zdarzenie - дослідження (aspekt dokonany), w języku rosyjskim i polskim - czynność i zdarzenie - исследованние, badanie [Jóźwikiewicz 2008, 146].

Rzeczowniki odczasownikowe mogą być używane jako parafrazy zdań $z$ orzeczeniami zarówno w stronie czynnej, jak i biernej bez zmiany znaczenia. Na to wskazuje nie tylko budowa morfologiczna rzeczownika odczasownikowego, którego podstawa jest imiesłów przymiotnikowy bierny, ale i podobna forma agensa w obu konstrukcjach: Słoiki, starannie myte przez aseptyczna ciotke Mirosławe, ujawniały swe sekrety [Jacek Dehnel]; Byłaś zbyt miła dla niego - powiedziałem, wycierajac myte przez Renię naczynia [Mariusz Ziomecki] - konstrukcja bierna $z$ imiesłowem, biernikiem i przyimkiem przez; Do snujacych się dźwięków dołaczył brzęk talerzy $i$ sztućców, niesionych do mycia przez Lidkę [Robert Urbański; Jacek Kondracki] - konstrukcja z rzeczownikiem odczasownikowym $z$ agensem $\mathrm{w}$ bierniku i przyimkiem przez.

W języku ukraińskim podobna konstrukcja występuje $z$ agensem w narzędniku: Mокрі, липкі від поту люди зринали і не могли зринути з сонного очманіння, борсалися в тяжккій атмосфері, як на дні моря, наснаженій тухлим смородом, надміром вуглекисню, терпкими випарами давно не митого милом тіла... [Софія Андрухович] konstrukcja $z$ imiesłowem. Після миття шампунем машина набуде свого натурального кольору, тобто білого [Віктор Савченко] - konstrukcja $z$ rzeczownikiem odczasownikowym.

Specyficzną cechą języka polskiego, częściowo czeskiego i słowackiego, sa tzw. zwrotne rzeczowniki odczasownikowe, które zachowuja zwrotny formant sie przy substantivum verbale, np.: Uczenie sie w najbardziej dosłowny i bezpośredni sposób, co oznacza wykorzenienie... [Kamila Sławińska]. O produktywności tych form świadczy tendencja do tworzenia takich form od nowych leksemów (instalowanie się, logowanie się), np. w tytule artykułu: Od „grzechu anielstwa” do „uważności”, czyli poezja jako instalowanie się w świecie [Marek Zaleski, „Teksty Drugie” 2011]. Jak zauważa Halina Safarewiczowa [Safarewiczowa 1954, 332], przyczyną tego zjawiska może być swobodne funkcjonowanie w zdaniu zaimka się i jego desemantyzacja w porównaniu $z$ językiem ukraińskim i rosyjskim, w których -cr złączyło się z czasownikiem: Zmuszają do obejrzenia sie, nawet do podążenia się za kobieta, które ich używa [Janusz Wiśniewski]. 
Kategoria przechodniości wyraża się przez funkcyjne podobieństwo rzeczownika w bierniku przy czasowniku przechodnim oraz rzeczownika w dopełniaczu przy rzeczownikach odczasownikowych, motywowanych przez czasowniki przechodnie: malować obraz - malowanie obrazu, obserwować ptaki - obserwowanie ptaków. Dopełniacz oznaczający obiekt $\mathrm{w}$ konstrukcjach $\mathrm{z}$ rzeczownikami odczasownikowymi utworzonymi od czasowników przechodnich jest regularna transformacja dopełnienia bliższego w bierniku.

Semantyka kategorii przechodniości / nieprzechodniości rzeczowników odczasownikowych wpływa na łączliwość i staje się cechą rozróżniajacca wieloznaczne rzeczowniki odczasownikowe. Rejestr semantyczny rzeczowników odczasownikowych: посвячення, скликання, покарання, пристосування, порівняння // podanie, badanie, nakrycie, zamknięcie, okrycie składa się $z$ dwóch lub więcej znaczeń, wśród których znaczenie pierwsze to określenie czynności, a drugie - określenie pojęcia, terminu, przedmiotu itd. Semantyka przechodniości i znaczenie rezultatu czynności są właściwościami jedynie rzeczowników odczasownikowych.

Rzeczowniki odczasownikowe zakończone na -nie, -cie maja przede wszystkim podobna walencję jak czasownik podstawowy (z przyimkiem lub bez), np.: pomagać przyjacielowi-pomaganie przyjacielowi, rzadzić krajem - rzadzenie krajem, rozmawiać o bracie - rozmawianie o bracie, pracować nad planem - pracowanie nad planem // допомагатu другові - допомога другові, керувати країною - керування країною, розмовляти про брата - розмова про брата, працювати над планом - праия над планом, ponieważ bardziej naturalnie brzmią konstrukcje $z$ czasownikiem.

Hybrydalne formy czasownikowe sa aktualnym i niewystarczająco zbadanym tematem badawczym, szczególnie w wypadku języków słowiańskich. Cechą charakterystyczna tych form odczasownikowych jest zachowanie semantyczno-składniowej kategorii walencji. Formy na -no, -to, imiesłowy przymiotnikowe, rzeczowniki odczasownikowe oraz bezokoliczniki zachowuja wszystkie pozycje walencyjne czasowników podstawowych, oprócz subiektu. Każda $z$ wyżej wymienionych form w pewnym stopniu wyraża cechy procesualne oraz naśladuje kategorie czasownikowe lub kategorie imienne, co daje podstawy do tego, aby traktować je jako czasownikowe, imienne lub hybrydalne.

Ukraiński imiesłów przymiotnikowy jest semantycznie bliższy przymiotnikowi, ponieważ wyraża cechę przedmiotu związaną $z$ wykonywana przez niego czynnościa lub właściwym dla niego stanem. W związu $z$ tym w języku ukraińskim naturalne sa konstrukcje $z$ imiesłowami, 
które wyrażaja stronę jako rezultat czynności lub wydarzenia, ale nie sa właściwe językowi ukraińskiemu konstrukcje imiesłowowe bierne, wyrażające czynność lub wydarzenie. Polskie imiesłowy przymiotnikowe zachowuja kategorie aspektu oraz strony, ukraińskie - tylko aspektu, w języku rosyjskim zaś - aspektu, czasu oraz strony. Należy zauważyć, że w języku ukraińskim, podobnie jak w polskim, formy imiesłowowe pełnia $\mathrm{w}$ zdaniu funkcje atrybutywne i predykatywne, w porównaniu $z$ językiem rosyjskim, w którym istnieja krótkie formy imiesłowów przymiotnikowych do wyrażania funkcji predykatywnej.

W języku ukraińskim bardziej rozpowszechnione sa konstrukcje $z$ bezokolicznikiem niż $z$ rzeczownikami odczasownikowymi, co jest spowodowane kulturowo-semantyczna tradycja poznawania świata przez czasownik. Język polski charakteryzuje intensywne tworzenie form imiesłowów przymiotnikowych oraz rzeczowników odczasownikowych, czego potwierdzeniem jest wiele neologizmów.

\section{Wykaz stosowanych skrótów}

\author{
biał. - białoruski \\ bułg. - bułgarski \\ czes. - czeski \\ ksiażk. - książkowe \\ lp. - liczba pojedyncza \\ mac. - macedoński \\ np. - na przykład \\ os. - osoba
}

$$
\begin{aligned}
& \text { pol. - polski } \\
& \text { r.m. - rodzaj męski } \\
& \text { r.n. - rodzaj nijaki } \\
& \text { r.ż. - rodzaj żeński } \\
& \text { ros. - rosyjski } \\
& \text { rzecz. - rzeczownik } \\
& \text { ukr. - ukraiński } \\
& \text { wg - według }
\end{aligned}
$$

\section{Bibliografia}

P. Bak, 1978, Gramatyka jezyka polskiego, Warszawa.

R. Grzegorczykowa, R. Laskowski, H. Wróbel, 1999, Gramatyka współczesnego jezyka polskiego. Morfologia, Warszawa.

P. Jóźwikiewicz, 2008, Ukraińskie rzeczowniki odczasownikowe na -Hн(я), -mm(r) - historia, funkcjonowanie, kontrowersje, „Roczniki Humanistyczne” t. LVI (7), Lublin, s. 141-149.

H. Koneczna, 1956, O budowie zdania Imćpana Paskowego słów kilkoro 3. Orzeczenia składajace się $z$ verbum finitum czasowników niezwrotnych $w$ formie III os. l. poj. + zaimek się, „Poradnik Językowy” z. 10, s. 385-391.

S. Mędak, 2004, Słownik form koniugacyjnych czasowników polskich, Kraków.

A. Nagórko, 2007, Zarys gramatyki polskiej, Warszawa.

NKJP: Narodowy Korpus Języka Polskiego, http://www.nkjp.pl [dostęp: 30.03.2021].

J. Puzynina, 1969, Nazwy czynności we wspótczesnym języku polskim (słowotwórstwo, semantyka, składnia), Warszawa. 
H. Safarewiczowa, 1954, Rzeczowniki „zwrotne” w języku polskim, „Język Polski” XXXIV, z. 5, s. 332-348.

Z. Saloni, 2012, Podstawy teoretyczne „Słownika gramatycznego języka polskiego", Warszawa.

J. Strutyński, 2002, Gramatyka polska, Kraków.

J. Tokarski, 1951, Czasowniki polskie: formy, typy, wyjatki, Warszawa.

USJP: S. Dubisz (red. nauk.), 2004, Uniwersalny słownik języka polskiego, Warszawa, wersja 1.0. [dostęp: 30.03.2021].

SJP: W. Doroszewski (red.), 1958-1969, Słownik języka polskiego, t. I-X, Warszawa, https://sjp.pl [dostęp: 30.03.2021].

H. Wróbel, 1975, Składnia imiesłowów czynnych we współczesnej polszczyźnie, Katowice.

H. Wróbel, 2001, Gramatyka języka polskiego, Kraków.

D. Wieczorek, 1994, Ukrainskij pierfiekt na -no, -to na fonie polskogo pierfiekta, Wrocław.

Й. Андерш, 1987, Типологія простих дієслівних речень у чесъкій мові у зіставленні з украӥнсъкою, Київ.

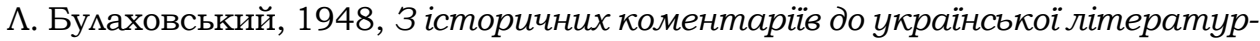
ної мови, „Наукові записки КДУ імені Т.Г. Шевченка” т. VII, bип. III, „Фімологічний збірник" nr 2, s. 25-50.

I. Вихованець, 1988, Частини мови в семантико-граматичному аспекті, Київ.

I. Вихованець, К. Городенська, 2004, Теоретична морфологія української мови: Академ. граматика укр. мови, Київ.

В. Виноградов, 1972, Русский язык. Грамматическое учение о слове, Москва.

М. Гінзбург, 2019, Особливості українсъкої мови шодо подавання проиесових понять у фахових текстах, „LANGUAGE: Codification Competence Communication" (1), s. 7-24.

Г. Гнатюк, 1982, Діеприкметник у сучасній украӥнській літературній мові, Київ.

К. Городенська, 2017, Граматичний стандарт українсъкої літературної мови і сучасна практика, „Граматичні студії” (3), s. 17-21.

М. Жовтобрюх, Б. Кулик, 1972, Курс сучасної украӥнсъкої літературної мови, сz. I, Київ.

Г. Козачук, 2007, Українсъка мова для абітурієнтів, Київ.

А. Кравчук, 2015, Польська мова. Граматика з вправами: Підручник для вищих навчальних закладів, Київ.

КУМ: Корпус української мови, http:/ / korpus.org.ua [dostęp: 30.03.2021].

О. Куримо, 2008, Уваги до сучасної украӥнсъкої літературної мови, Київ.

А. Пешковский, 2001, Русский синтаксис в научном освешении, Москва.

Е. Пчелинцева, 2016, От глагола к имени: аспектуальность в русских, украинских и польских именах действия, Санкт-Петербург.

О. Пчелінцева, 2019, Функиіонально-граматична специфіка українських віддієслівних іменників зі значенням дї̈ на фоні інших слов'янсъких мов, „Термінологічний вісник”, wуd. 5, Київ, s. 33-40.

В. Русанівський, 1968, Порівняльно-типологічна характеристика дієслівного стану в сучасних слов'янсъких мовах, Київ.

СУМ: 1970-1980, Словник українсъкої мови: в 11 тт., ред. І. Білодіда. Київ, http://sum.in.ua/ [dostęp: 30.03.2021]. 
Н. Щербій, 2014а, Граматична сполучуваність виразу sіе в польсъкій мові в порівнянні з українською мовою (постфікс -ся), „Науковий вісник міжнародного гуманітарного університету, серія: "Фіцоцогія", wyd. 9, s. 44-48.

Н. Щербій, 2014b, Безособові рефлексивні конструкиї̈ в украӥнській $і$ польсъкій мовах [w:] О. Паламарчук (red.), Компаративні дослідження слов'янських мов і літератур: Пам'яті академіка Меоніда Булаховсъкого: зб. наук. праць, wуd. 24, Київ, s. 215-222.

Н. Щербій, 2016, Категорія зворотності дієслів у польсъкій мові: автореф. дис.... канд. фрілол. наук: 10.02.03, Київ.

\section{Hybrydalne formy czasownikowe $w$ jezyku polskim $i$ ukraińskim}

\section{Streszczenie}

Hybrydalne formy czasownikowe sa aktualnym i niewystarczajaco zbadanym przez językoznawców zagadnieniem. W artykule dokonano opisu hybrydalnych form czasownikowych $\mathrm{w}$ celu porównania ich $\mathrm{w}$ materiale pochodzącym $z$ języka polskiego i ukraińskiego, analizy tych form ze wspólnego punktu widzenia procesualności. Hybrydalność polega na formowaniu części mowy, które łącza w sobie kategorie charakterystyczne dla różnych (werbalnych i imiennych) klas leksemów, np.: strony, czasu, zwrotności, przypadka oraz liczby. Do takich form zalicza się: rzeczownik odczasownikowy, imiesłów przymiotnikowy, bezosobowe formy na -no, -to oraz bezokolicznik. Zastosowanie metody porównawczej umożliwiło wyodrębnienie wspólnych i odmiennych cech w obu językach oraz scharakteryzowanie stopnia bliskości z czasownikiem czy rzeczownikiem, szczególnie dzięki kategorii zwrotności, chociaż jest to tylko formalna zbieżność $z$ formami zwrotnymi. Wszystkie wyżej wymienione części mowy łączy wspólna kategoria aspektu. Stwierdzono produktywność procesu tworzenia rzeczowników odczasownikowych.

Słowa klucze: formy czasownikowe - rzeczownik odczasownikowy - imiesłów przymiotnikowy - imiesłów przysłówkowy - bezosobowe formy na -no, -to bezokolicznik.

\section{Hybrid verb forms in Polish and Ukrainian}

\section{Summary}

Hybrid verb forms constitute a relevant aspect that has been little studied by linguists. The paper discusses hybrid verb forms in order to determine structural and semantic differences against the background of Polish and Ukrainian. The hybridity of verb forms lies in the formation of parts of speech that combine categories characteristic of different classes of words, such as voice, tense, reflexivity, case, number. Such forms include the verbal noun, 
adjectival participle, impersonal predicative forms ending with -no, -to, and infinitive. The use of the comparative analysis made it possible to separate common and different features in both languages. Polish and Ukrainian are characterised by different degrees of convergence with verb or noun, in particular due to the category of reflexivity. The paper states that all these mixed parts of speech are united by the category of aspect, which relates primarily to verb. The paper also analyses the functioning of hybrid verb forms in modern Polish and Ukrainian.

Keywords: verb forms - verbal noun - adjectival participle - adverbial participle - impersonal forms ending with -no, -to - infinitive.

Adj. Monika Czarnecka 